\title{
Angel Investing from the Perspective of the Entrepreneurs in Turkey
}

\author{
Yilmaz Bayar ${ }^{1}$, Mustafa Halid Karaarslan ${ }^{2} \&$ Cahid Ozdeveci ${ }^{2}$ \\ ${ }^{1}$ Department of Economics, Usak University, Usak, Turkey \\ ${ }^{2}$ Department of International Trade and Business, Karabuk University, Karabuk, Turkey \\ Correspondence: Yilmaz Bayar, Department of Economics, Usak University, Usak, Turkey. E-mail: \\ yilmaz.bayar@usak.edu.tr
}

Received: July 12, 2015

Accepted: August 5, 2015

Online Published: August 25, 2015

doi: 10.5539/ibr.v8n9p116

URL: http://dx.doi.org/10.5539/ibr.v8n9p116

\begin{abstract}
Business angels became an important financing source for the enterprises in the early stage of development in the world as of 1960s. However angel investing belatedly emerged in Turkey during the late 2000s. This study examines the angel investing process in Turkey from the perspective of entrepreneurs who benefited from the business angels by making in-depth interviews with 12 entrepreneurs. We found that the business angels are nearly the only financing source for unfinished product and business model and the experiences and networking of the business angels were important as well as their financing support.
\end{abstract}

Keywords: entrepreneurship, business angels, angel investing

\section{Introduction}

The entrepreneurship is one of the drivers behind the economic growth, because entrepreneurs establish ventures and ventures in turn mean new jobs, increase the competition and also raise the productivity by technological progress (Acs, 2006). In another words the process from the venture to the successful firm feed the economic growth through causing the increases in productivity and technological progress. Consequently the entrepreneurs are important economic actors for the sustainable business and economic growth.

The entrepreneur generally needs external financing especially at the first stages of their ventures and private equity, which is composed of venture capital and angel investing, is major financing source for the entrepreneurs. Both business angels and venture capitalists make investments in entrepreneurial firms in return for taking equity from the businesses. But there are some key differences between two financing sources. Firstly business angels use their own money for the investment, while venture capitalists use the funds obtained from the other sources such as insurance companies, pension funds etc. Secondly business angels generally make their investment in the early stage of the company development such as seed, start-up and early-stage businesses, while venture capitalists make investments in the businesses at the later stages. Thirdly the size of angel investing is about ( $\$ 5,000$ to $\$ 100,000$, while the investment size of venture capitalists is about $\$ 2$ million and up (Angel Capital Association, 2015). Therefore, business angels become important especially for the seed, start-up and early-stage businesses. Business angels are generally defined as private equity investors who invest their own money in start-up companies and also contribute to the businesses by giving support in the areas of management, accounting and finance, marketing and networking (Lange, Leleux, \& Surlemont, 2003). Business angels have provided financing many well-known businesses including Amazon, Apple, Facebook, Ford Motor Company, Bell Telephone (Gregson, 2014)

The number of business angels has increased significantly during the past 50 years (Mckaskill, 2009, p. 3). About 73,400 ventures got angel financing in 2014 and the number of active business angels was 316,600 individuals in 2014 (Center for Venture Research, 2015). Europe and the US are the leading angel markets. The share of the business angels in the $€ 7.5$ billion value of early stage investment market in the European region was about $€ 5.5$ billion in 2013 (EBAN, 2014, p. 2). The United Kingdom was the leader country of the European angel market with $€ 84.4$ million and Spain, Russia and France were the other big actors of the European angel market (EBAN, 2014, p. 5). On the other hand the amount of angel investing was about USD 22.9 billion in 2012 and the number of business angels was more than 268,000 in the US in 2012.

However, Turkey belatedly experienced the entrepreneurial activities due to the inappropriate investment climate arisen from political and economic instability for a long time. Turkey began to experience entrepreneurial 
activities as of 2003 together with gaining the political and economic stability relative to the past decades and increases in the credit ratings. Turkish government also made the regulation (Code 6327: Amending the Individual Pension Savings and Investment System Law and Certain Laws and Statutory Decrees) which established the infrastructure for angel investing in June 2012 and tax reliefs are provided for the angel investing within the context of this regulation (Bayar, 2013, p. 364). There have been 9 accredited business angel networks and these business angel networks host about 537 business angels (301 licensed and 236 unlicensed) (Undersecretariat of Treasury, 2015, p. 15).

The objective of the study is to evaluate the angel investing from the perspectives of the business angels who have taken angel investing and reveal the pros and cons of the angel investing. And also this study is aimed to enable the entrepreneurs to evaluate themselves from the perspectives of the entrepreneurs, make recommendations to the entrepreneurs who plan to get angel investing and provide some implications on the angel investing for the policymakers. There have been extensive studies on the business angels, their characteristics and their contributions. But this study will be one of the pioneering studies on the angel investing from perspective of the entrepreneurs who have taken angel investing in the literature. The rest of the paper is organized as follows. The next section presents research design, interview findings and discussion and Section 3 presents conclusions and policy implications.

\section{Research Design, Interview Findings and Discussion}

\subsection{Research Design}

We examined the angel investing from the perspectives of the entrepreneurs who benefited from business angels in Turkey. In this regard we conducted in-depth interviews with 12 entrepreneurs by face-to-face, internet and telephone. We found the contact information of the entrepreneurs in the web sites of business angel networks. Our interviews took about 40 minutes on average and the data was collected by semi-structured interview. In the context of the review, we asked the following questions to the entrepreneurs:

- Could you tell us about the process from the invention of new business idea to reaching a deal the business angel?

- What kind of contributions did you expect from getting into a partnership with the business angel?

- What kind of things did you pay attention to make use of these expected contributions from the business angels at the very most while forming a partnership with the business angel?

-At what extent did your business angel satisfy your expectations?

- Did you think that the business angel made any negative contributions to your business?

- What kind of advices do you give to the entrepreneurs about benefiting from the business angels?

We used the codes of E1, E2, E3, E4, E5, E6, E7, E8, E9, E10, E11 and E12 to express the views of the entrepreneurs in the study.

\subsection{Interview Findings and Discussion}

\subsubsection{Process Prior to the Agreement with Business Angels}

The views of the 12 entrepreneurs showed that business angels are nearly the only financing source for the unfinished products and the business ideas and venture capitalists and business angel networks generally finance the concrete and finished products and business models.

E11:"We began to search the investor with our prototype. At first we went to the big venture capital companies. We did not get any support from them because there were no finished products and no proven business model. We got the negative answers from them. Then we went to the business angel networks and we got similar impulses. They told us we could not invest for a product which has not finished. Finally we found a business angel. He and his friend, totally we three persons have made investment and our investment was at the stage of prototype."

E10: "He searched the investor after developing his product by taking research and development (R\&D) support from the university."

E10, “...We established a R\&D group. We worked during the six months and made the prototype six months later. I waited about 1.5 years for the business angel... 1.5 year... I said myself that we were ready. Then we got the investment from the business angel in three months."

Two of the entrepreneurs (E2 \& E9) in our study got angel investment from the persons who they recognized 
before.

E2: "We had a family friend we recognized before. He and another angel, two angels, became my business partners and we got investment from them."

The entrepreneurs may not always search investment from the business angels. E6 said that he got investment proposal from the business angels. On the other hand E4 he does not need the investment from the business angels.

E4: "We are generally prone to think that we stand on our own two feet. But we needed the investment from the business angels. We realized this consideration later. We had the chance to meet our business angels during an activity."

On the other hand E6 and E7 financed their projects by their current wages obtained from their salaried employments in the first stages of their ventures.

E6 : "I provided all the financing requirements of the venture until I formed the company. Business angels have become a part of the business since 2008."

\subsubsection{The Expectations of the Entrepreneurs from the Business Angels}

Most of the entrepreneurs stated that they expected financial support from the business angels. Even some entrepreneurs expected only money from the business angels. However some entrepreneurs had the expectations to take advantage of the experiences, networking of business angels. On the other hand angel investing in a venture also had an increasing impact on the motivation of the entrepreneurs and the workers of the venture.

E1: "Our primary focus was money... Networking contribution... The networking for a clever entrepreneur was purchasable things in many structures."

E11: "Primarily money because we need to develop the product with the money ... We planned to go to the venture capital companies after the development of the product. This thought realized. We had no other expectations."

However, some entrepreneurs had expectations to benefit from the experiences and networking of the business angels as well as financial expectations.

E4: "The only thing we expected from the business angels was honestly money. But we understood that the experiences and networking of business angels were more important than money as time progressed. We did not originally see this ...".

E2: “.. to benefit from the experiences of the business angels is very important for us ... They told us which business models were not useful in advance. This enabled us to save from labor and money."

E6: "First of all... networking... That business angels make investments in a venture really means a signal for all the other business angels and institutional investors. It meant there was a value here and I made investment in this value ... know-how... experience... cash... for the faster growth of the company."

E8: "Morale, motivation...advice... networking ... money..."

E10: "I expected that they dedicated themselves to the work as I did."

E12: "We expected networking, financial support and appropriating the business from business angels."

\subsubsection{The Coverage of the Expectations of the Entrepreneurs from the Business Angels}

Our interviews with the entrepreneurs demonstrated that the business angels satisfied their expectations considerably, even business angels contributed to the ventures above the expectations of the entrepreneurs.

E11: "business angels gave us money and we gave the account of that money ... the only thing we wanted from them was money, on the other hand the only thing which the business angels expected from us was that we used the money in a good way"

E1: “... I had no expectations except money. The business angel introduced the money and had much effect on the getting the second angel investing. Also he had much effect on the selection of the current situation ... They supported us to undertake the new businesses and they went to make interviews by themselves when required..."

E2: "Most of the business angels introduced considerably... They were be more beneficial than we expected."

E3: "He satisfied my expectations ... I got the investment which I wanted. They supported me seriously. I 
am very glad to experience the angel investing. He helped me to enlarge my team... feedback me about the job... to introduce me to somebody about some critical issues."

E9: "We expected the business angels to help us about collection methods and they did ... This was important... Our relations with search engines and social networks were strengthened... We did not expect this. They met my expectations completely"

E12: "We reached the point we could have not come in 6-7 months in 6-7 workdays together with them. We learned how to start and manage a business, to finish job, to make a bargain, consequently business world has its rules and we learned them. We started as students in this venture ..."

Some entrepreneurs thought that the business angels retarded them in case they got angel investing from a group of business angels.

E4: "They availed us substantially, but our job also slowed down in some places."

E5: "The business angels began to direct their network and business to us before we did not get angel investing and countersign the partnership yet. Moreover the business angels do not have much free time. This is also a separate issue which should be discussed. Consequently he should pass at least two hours a two weeks with me that he can really give us mentorship... I could say we did not about this issue what we wanted."

E7: "We should have had better employees. Every person has chance to do 4-5 jobs simultaneously abroad. They has many jobs, so they cannot allocate time to us."

E10: "You expect many things from the business angels, you are an entrepreneur ... The entrepreneur exploits very well ... exploits money and uses all the sources. I had many expectations. I never satisfied because I had many expectations. Capital is a small part of the job... You can also get the money from the banks... Institutionalization... functioning of the organization and business plan... networking ... establishing the team... opening to the new markets especially foreign market... They did not meet anything except human resources."

\subsubsection{The Negative Aspects of Angel Investing}

The findings of the interviews showed that the negative sides of the business angels were their harsh reactions, insufficient interest, considerable bureaucratic procedures, waste of time due to unnecessary demands of the business angels. A small part of the business angels had capital problems and did not have the minimum required qualifications.

E8: “...The business angels reacted harshly in some cases. After all we are business partner... They could give better reactions."

E10: “...Whenever we called him, he talked with us. Whenever we demanded something from him, he always did his best. The thing that should have been was that he had seen our and deficiencies by himself and corrected our deficiencies."

E7: "The business angel made overtures about buying the $70-80 \%$ of the firm and in return the money he offered was too comic."

E5: "If the business angel did not allocate much time for us and he was in the right frame of mind to deal with nothing except only giving money. This was a negative situation for us. Consequently you cannot benefit from them. We thought the angel investing as a purpose, it took plenty of time ... about 7-8 months... That it took so much time caused us to lose our focus. We could have developed our product faster and proceeded in the market faster... Too much bureaucracy and unbelievable long contracts were loss for us. Normally a contract with 10 pages was enough for angel investing, our contract was 82 pages and it was more than a venture capital contract... Sometimes we felt sorry for this. We thought by ourselves if only we had not taken angel investing. Because if we had focused our job for so much time, maybe we had been in much further position than we were despite the angel investing. The time we lost was about 7-8 months. The bureaucratic transactions and mailings among the investors, negotiations, dawdling... We sent e-mail, they answered 4 days later. Why? Because their job was not angel investing... This was the worst aspect of the angel investing."

E3: "The time of the entrepreneur is valuable... If the entrepreneur has to explain everything to the partner, it will be problem... If he always included the process in the areas which he was not experienced and an entrepreneur does not prefer a business angel who involves everything... Of course if the he has benefit ... Sometimes there may be differences arisen from the generation differences. The usage of the business angel may be different from the operation of a start-up business."

E1: "A person with USD 20000 calls himself or herself as business angel. The business angels in Turkey 
also do not have sufficient capital .... They also should have a lot of things to learn."

\subsubsection{Further Recommendations on the Angel Investing}

The findings of the interviews with the entrepreneurs demonstrated that the venture should be materialized before applying to the business angels to provide financing.

E10: "The entrepreneur should expand his or her business and venture should be sustainable... If the scalable larger organization reaches a point which it becomes a more corporate structure and produces more new products and opens new markets, he should consult with business angels."

E2: "The entrepreneur should go to the business angel with a good business plan and be open in all the issues. Everything should be transparent. A fiduciary relationship..."

E8: "They do not lie to the business angels... For example our venture is very good ...You can act like small-minded person and think to affect the business angel more with the excitement in that moment. Consequently you speak transparently when they make the final decision... It is nice thing to have the chance that I put something bad in the past straight in the future ..."

The findings of the interviews showed that the entrepreneurs should not abstain from sharing the business idea with business angels.

E9: "The entrepreneurs may avoid sharing their ideas... They can be afraid of their ideas stealing. There have been about 50,000 persons who think to establish a dating site nowadays. We have been doing an unoriginal business ... Everybody can think of this ... We are leader in terms of use count... Action, not idea, is important. Therefore the entrepreneurs should share their ideas without fearing. To avoid meeting with an investor so as not to share his or her ideas is the worst thing that the entrepreneurs experience. The entrepreneurs should meet with many business angels as far as possible. They should express their business ideas to many business angels as far as possible. If you are about to look for financing, you should meet with 20 different investors a week as far as possible. What the more professional business angels look at how they exit from the venture in the future. The ones who do angel investing for pleasure look at this consideration less often. Therefore you should show them who can buy this firm in the future. This is very important."

The findings of the interviews also demonstrated that the entrepreneurs should contact with the entrepreneurs who took angel investing before.

E9: "The entrepreneurs who plan to get financing from a business angel should look at the other investments of the business angel. Are the other entrepreneurs who took angel investing from the investor are happy? If these entrepreneurs are happy, there is nothing to be afraid of."

The entrepreneurs also are ready to reject the investment offer of the business angels when needed and they should be earning money for the negotiating power.

E1: "They should be in that environment... They will seek the favorable for them by declining the first claims politely... Their money is important but it is disputable whether the first money is important or not. They should be strong as entrepreneurs .... They should be earning money. You should exhibit acceleration even you do not earn money."

The entrepreneurs also suggested that the ones who plan to get angel investing will make task sharing and they do not allow the business angel to involve the each business. The terms of pre-angel investing should be analyzed well. But one of the most important constraints for the entrepreneurs is insufficient number of business angels.

E11: "They specify mutual expectations well. The entrepreneurs do not allow the business angels to involve their day works, because they take in partnership by depending on the entrepreneur. They do not take in partnership to run the business."

E4: "I suggested that the entrepreneurs should analyze the investor very well while getting angel investing. The experiences of the business angels and their network are more important than the money is..."

E6: "They should select the business angel well... they do not allow the business angel to involve daily operations... they analyze that who has which rights very well while arranging memorandum of association or articles of partnership. I do not think that the entrepreneurs do have chance to select his or her business angel..."

E7: "There are rules which enable the partnership structure to run well... They should do their homework well about how the management structure should be, how many stocks they should give, how much money they should take and how the valuation should be conducted. You should determine how many stocks you should sell 
and how much money you get and at which stage (while you have business idea or you develop the product) you get the angel investing. An agreement you made at outset should not oblige you... Because it is nearly impossible to find the business angel in Turkey, the entrepreneurs jump at when they find the business angel. If there is chance to negotiate in the ideal world, the entrepreneurs should consider my sayings and meet with them by making preparations."

Our findings also indicated that the entrepreneurs should care that the number of business partners are over. The existence of many businesses partners both causes the relationship management to aggravate and causes the business investors to motivate insufficiently because their share in the firm is low.

E9: "We are a firm with more than 20 business partners... This compels us partially... It could be better we had less business partners. When you get angel investing in the different stages of the company development, the investors may have different expectations."

E5: "More than 4 business angels are too unnecessary. When the number of business angels increases, the share of the business angels in the firm approaches to the $1 \%$... You become a low valuable venture for him... But if there are 4 business angels and each one has about $5 \%$ of the firm shares, they devote some time."

E4: "The paperwork may be lengthened out due to overcrowded partnership structure .... It can be hard to meet with them, because the business angels are very busy."

The findings showed that especially the entrepreneurs who do not have business experience should prefer the business angels having enough time for them while selecting the business angel.

E8: "You try to go into a partnership with the business angels who can allocate time for you as far as possible. They should avoid the people who only give money if they feel... They find the people who embrace and give some thought to the work."

The entrepreneurs also should give place to time constraints at the investment agreements to avoid the possible delays of the process.

E5: "When we decided to get the angel investing, our revenue was about 3000 Turkish liras. 8 months later, when we got the angel investing, our revenues increased to 40000 Turkish liras. Our valuation stayed too low. They should set time limits for everything and punish the timeouts... For example this agreement will be completed in 2 months, otherwise the valuation will be negotiated again ... or their share in the firm will be decreased."

Our findings demonstrated that if the business angels are experienced and have relations with the other business angels, these points will increase the contributions from the business angels.

E3: "If you choose the right business angels, the business angel will benefit to you from the right points. If you do not find the right business angel, he may not benefit to you. If the business angel involves nothing in the firm, this is also not a bad thing.. If the business angel involves everything in the firm, this is also not too good... The people within the ecosystem generally find the right people who involve the work in right points and right time."

The business angels and the entrepreneurs are mutually complementary components. The business angels try to earn money while they contribute to the entrepreneurs expanding their ventures.

E12: "If you start a business $100 \%$, this is by virtue of the business angel. Did I have network? Did I have money? How I could start the business! The business angel came and made investment, introduced his networking ..."

E7: "The business angels are businessmen and consequently try to earn money... Of course sometimes we are tensed, but the relationships are professionally wonderful, but it cannot be as thick as thieves, because it is against their nature... I mean that the business angel took risk on you... We will be stressed and sometimes we will dissent. We can say that this job is mentality and a relationship based on self-interest... We got the angel investing, because our interests are compatible with the interests of the business angels. I would like to start up the business by myself... The business angel also would like to earn 10 Turkish liras in exchange for each 1 Turkish lira. But we try to find a happy medium.

Finally the business angels suggested that every entrepreneur try to get angel investing from the business angels when necessary.

E5: "Everybody should try." 


\section{Conclusion}

The entrepreneurs became the important actors behind the sustainable business and economic growth and they generally need the external funds at the early stages of their ventures. In this regard, the angel investing is one of the leading financing sources for the start-up firms. We examined the angel investing process in Turkey from the perspective of entrepreneurs who made use of angel investing by conducting in-depth interviews with 12 entrepreneurs. We asked the entrepreneurs to evaluate the process of the angel investing and also asked them what they expected from the business angels and what they got from them. Finally we asked the entrepreneurs what the negative aspects of the angel investing were and what they suggest for the entrepreneurs who will get angel investing in the future.

Our major findings of the interviews with the entrepreneurs were as follows:

Business angels are nearly the only financing source for the unfinished products and the business ideas.

Business angel networks generally finance the concrete and finished products and business models.

The entrepreneurs generally expected financing from the business angels. However they also expect the business angels to provide premiumization, benefit from the experiences and networking of the business angels, attracting more talented employees, increase the motivation of the entrepreneurs and employees.

Some entrepreneurs made a complaint about the business angels not allocating sufficient time for them. Also the other negative sides of the business angels were their harsh reactions, insufficient interest, considerable bureaucratic procedures and waste of time due to unnecessary demands of the business angels.

The entrepreneurs suggested that venture should be materialized before applying to the business angels to provide financing, the entrepreneurs should share their business ideas with the business angels and do task sharing and they do not allow the business angel to involve the each business.

Our findings showed that the business angels are important actors for the entrepreneurs, in turn for the creation of employment. The business angels do not provide only financing, but also introduce their business experiences and networking to the business angels. Therefore, the policymakers should consider the creating an appropriate investment environment for the business angels.

\section{References}

Acs, Z. (2006). How is the entrepreneurship good for economic growth. Innovations, 1(1), 97-107. http://dx.doi.org/10.1162/itgg.2006.1.1.97

Angel Capital Association (2013). SEC Advisory Council on small and emerging companies. Retrieved from http://www.sec.gov/info/smallbus/acsec/acsec-091713-verrill-hudson-slides.pdf

Angel Capital Association. (2015). FAQs for angels \& entrepreneurs. Retrieved from http://www.angelcapitalassociation.org/faqs/\#What_is_the_difference_between_angels_and_venture_capita lists

Bayar, Y. (2013). Angel financing in early stages of company development. International Journal of Economics and Finance Studies, 5(1), 359-367.

Centure for Venture Research. (2015). The angel investor market in 2014: A market correction in deal size. Retrieved https://paulcollege.unh.edu/sites/paulcollege.unh.edu/files/webform/2014\%20Analysis\%20Report.pdf

EBAN (2014). Statistics compendium. Retrieved on May 29, 2015 from http://www.eban.org/wp-content/uploads/2014/09/13.-Statistics-Compendium-2014.pdf

Gregson, G. (2014). Financing new ventures: An entrepreneur's guide to business angel investment. New York: Business Expert Press.

Lange, J., Leleux, B., \& Surlemont, B. (2003). Angel networks for the 21st century: An examination of practices of leading networks in Europe and the US. Journal of Private Equity, 6(2), 18-28. http://dx.doi.org/10.3905/jpe.2003.320036

McKaskill, T. (2009). An introduction to angel investing: A guide to investing in early stage entrepreneurial ventures. Melbourne: Breakthrough Publications.

Undersecretariat of Treasury. (2015). Bireysel katılım sermayesi sistemi ilerleme raporu. Retrieved from https://www.hazine.gov.tr/File/?path=ROOT\%2F1\%2FDocuments\%2FSayfalar\%2FBKS+RAPOR+2015\% 2FBKS+\%C4\%B0LERLEME+RAPORU+N\%C4\%BOSAN+SAYISI.pdf 


\section{Copyrights}

Copyright for this article is retained by the author(s), with first publication rights granted to the journal.

This is an open-access article distributed under the terms and conditions of the Creative Commons Attribution license (http://creativecommons.org/licenses/by/3.0/). 